УДК 656.611.2:005.366.1(049)

JEL L 29,P 45,R 40,D 81

DOI 10.31375/2226-1915-2020-3-109-120

\section{УПРАВЛІННЯ ЕФЕКТИВНІСТЮ \\ ТОРГОВОГО СУДНОПЛАВСТВА З УРАХУВАННЯМ СИСТЕМИ РИЗИКІВ}

О.В. Сенько

д.е.н., професор кафедри менеджмент та економіка морського транспорту o.sienko@onma.edu.ua https://orcid.org/0000-0003-2076-8503 А.Ю. Стахов

магістр факультету

Морське право та менеджмент

Національний університет «Одеська морська академія», Одеса, Украӥна

Анотація. 3 посиленням ролі морського транспорту у забезпеченні усталеності міжнародних відносин зростають вимоги до надійності торговельного флоту. Саме ие стає найважливішим поміж сукупності факторів надійності функиіональної діяльності морських транспортних підприємств. Водночас необхідно враховувати прояви низки негативних наслідків масштабного транспортного освоєння світового океану. Зазвичай враховується зростання техногенного навантаження на природне середовище та зберігаються ризики аварійних ситуацій. Тому на етапі посилення ролі інновачійних технологій найважливішим стає збереження підприємницькоі ефективності проектів розвитку торгового судноплавства з урахуванням посилення ролі адміністрування з боку Міжнародної морської організації. У ицих обмеженнях важливо переглянути традииійні підходи до окремих питань менеджменту судноплавства.

Ключові слова: торговельне мореплавство, ефективність, підсистеми глобального ринку, система ризиків, інновамійні технології, міжнародна торгівля.

() Сєнько O.B., Стахов А.Ю., 2020
УДК 656.611.2:005.366.1(049)

JEL L 29, P 45,R 40,D 81

DOI 10.31375/2226-1915-2020-3-109-120

\section{УПРАВЛЕНИЕ ЭФФЕКТИВНОСТЬЮ ТОРГОВОГО СУДОХОДСТВА С УЧЕТОМ СИСТЕМЫ РИСКОВ}

Е.В. Сенько д.э.н., профессор кафедры менеджмент и экономика морского транспорта o.sienko@onma.edu.ua A.Ю. Стахов магистр факультета Морское право и менеджмент

Национальный университет "Одесская морская академия». Одесса, Украина

Аннотация. C усилением роли морского транспорта в обеспечении устойчивости международных отношений возрастают требования $\kappa$ надежности торгового флота. Именно это становится важнейшим среди совокупности факторов надежности функииональной деятельности морских транспортных предприятий. Одновременно необходимо учитывать проявление ряда отрицательных последствий масштабного транспортного освоения мирового океана. Обычно учитывается возрастание техногенной нагрузки на природную среду и сохраняют риски аварийных ситуаций. Поэтому на этапе усиления роли инновационных технологий важнейшим становится сохранение предпринимательской эффективности проектов развития торгового судоходства $c$ учетом усиления роли администрирования со стороны Международной морской организачии. В этих ограничениях важно пересмотреть традиичонные подходы $\kappa$ отдельным вопросам менеджмента судоходства.

Ключевые слова: торговое мореплавание, эффективность, подсистемь глобального рынка, система рисков, инновачионные технологии, международная торговля. 
UDC 656.611.2:005.366.1(049)

JEL L 29, P 45, R 40, D 81

DOI 10.31375/2226-1915-2020-3-109-120

Olena Sienko

Doctor of Economics, Professor of the Department of Management and Economics of Maritime Transport https://orcid.org/0000-0003-2076-8503

o.sienko@onma.edu.ua

Arsenii Stakhov

Master of the Faculty of Maritime Law and Management

National University «Odessa Maritime Academy», Odessa, Ukraine

\title{
MERCHANT SHIPPING EFFICIENCY MANAGEMENT WITH ALLOWANCE FOR THE SYSTEM OF RISKS
}

\begin{abstract}
The increase in the role of the maritime transport in the international trade determines the tasks of development of the corresponding productive capacity of shipping companies and merchant ports. In accordance with this, the need for enhancement of the technical and ecological fleet reliability and for reduction of the probability of various risks in the stable positioning of the subsystems of the global seaborne trade market is rising. In line with the positive results of development of the national economic potential of the maritime transport industry, the totality of risks and threats emerges. It is this block of functional activity of the merchant fleet and seaports that determines the tasks and problems of the management and innovative development. The versatility of the results of the economic potential formation in the maritime transport industry determines the complications in decision-making in the system of the large number of operators that seek for the solution of the same main task. At the same time, in addition to competitive contradictions, the probability and directions of avoiding various risks inherent in the sea-borne trade market are to be taken into account.

It is necessary to differentiate the approach to minimisation of risk manifestation depending on the nature of their controllability. From this point of view, the projects to expand the innovative technologies and the tasks of timely consideration of the negative manifestation of negative extern alities stand out. The latter, despite the severity of manifestation, may be considered in the projects of innovative compliance. However, it is not enough to consider only the negative manifestation of the external factors among the risks. It is necessary to single out the sustainability risks, determined by the general development of the competitive advantage in the system of the sea-borne trade market.

While the role of maritime transport in ensuring the stability of international relations is increasing, the requirements for the reliability of the merchant fleet run high. This becomes the most important characteristic among the totality of reliability factors of the functional activity of sea transport enterprises. At the same time, it is necessary to consider the manifestation of a number of negative consequences of large-scale transport development of the world ocean. Usually, an increase in the technogenic load on the natural environment is taken into account and the risks of emergencies remain.

Therefore, at the stage of strengthening the role of innovative technologies, the most important thing is to maintain the entrepreneurial efficiency of projects for the
\end{abstract}


development of merchant shipping, considering the strengthening of the role of administration on the part of the International Maritime Organization. In these constraints, it is important to revise the traditional approaches to certain issues of shipping management.

Keywords: merchant shipping, efficiency, subsystems of the global market, system of risks, innovative technologies, international trade.

Постановка проблеми. Масштабний вплив морської транспортної індустрії на стабільність та ефективність міжнародних економічних відносин зумовлюе виникнення різних завдань ефективного стану флоту і торгових портів за критеріями підприємництва. Водночас ускладнюється формування морського транспортного потенціалу та ефективного його управління у системі зовнішніх обмежень та проявів стандартних i нових ризиків. Складна сукупність проблем сталого розвитку зумовлює необхідність термінового вирішення конкретних ситуацій.

За будь-яких умов пріоритетним для економічної безпеки позиціонування національної економіки у міжнародному поділі праці виявляється відповідний розвиток структурних підсистем морегосподарського комплексу. При цьому необхідно розділяти підприємницькі інтереси, завдання макроекономічного зростання та умови, що склались у системі глобального ринку морської торгівлі.

Незважаючи на десятки законів, постанов та концепцій розвитку морського транспорту, жодне рішення про становлення України як морської держави у XXI столітті не було виконано. Це говорить, по-перше, про непрофесіоналізм органів державного управління, i, по-друге, про відсутність реальних заходів для підтримання підприємницьких стратегій розвитку конкурентного національного флоту.

Тому увагу зосереджено на проблемі своєчасності реакції на системні зміни у системі глобального ринку морської торгівлі.

Огляд останніх досліджень та літератури. Системне значення морської транспортної індустрії для сталого позиціонування учасників міжнародного поділу праці визначає необхідність дослідження поточних особливостей розвитку галузі. Тому виникають різні підходи авторів до оцінки ситуації в усталеності позиціонування операторів у системі ринку морської торгівлі [1-3].

Водночас необхідно враховувати, що для всіх спеціалізованих сегментів торговельного судноплавства характерним $\epsilon$ прояв сукупності ризиків. Вони пов'язані з характером зовнішнього впливу на диференціацію окремих стадій життєвого циклу [4], а також залежать від характеру реакції власників на їх зміни. Особливо це відбивається на характері валютних ризиків. Змінення за цією умовою конкурентоспроможності розглядається у сучасних дослідженнях [5]. Важливо уникнути зниження участі в обслуговуванні вантажопотоків навіть за умови зміни маршрутів для експортних вантажопотоків. Часто завантаження терміналів трансформується у зв'язку з тим, що вантажопотоки йдуть на конкурентні портові потужності. 
DEVELOPMENT OF MANAGEMENT

AND ENTREPRENEURSHIP METHODS ON TRANSPORT, № 3 (72), 2020
РОЗВИТОК МЕТОДІВ

УПРАВЛІННЯ ТА ГОСПОДАРЮВАННЯ

НА ТРАНСПОРТІ, № 3 (72), 2020
Особливо чітко необхідно стежити за процесами, пов'язаними з завершенням дії стратегії [6], котра передбачала «перехід до інтенсивного типу розвитку» та «розширення міжнародних транспортних зв'язків» 3 метою ефективного використання транзитного потенціалу. Водночас слід відзначити посилення формування асиметрії у розподілі провізної здатності торгового флоту за прапорами держав, здатних реалізувати пріоритет інноваційних технологій. Тому такі країни, як Україна, обмежені у використанні інноваційних ресурсів для розвитку.

Постановка задачі. У якості основної цілі матеріалу статті розглядається систематизація характеру впливу різних факторів на системну безпеку розвитку морської транспортної індустрії країни. При цьому увага акцентується не лише на стандартному підході до оцінки та управління безпекою мореплавства. Як системна безпека розглядається досягнення сукупності результатів стандартної функціональної діяльності торгового флоту та портів за основними підсистемами мегаекономіки.

Разом 3 орієнтацією на збалансованість попиту та пропозиції за конкурентних умов позиціонування окремими морськими транспортними компаніями принциповою лишається необхідність контролю характеру прояву різноманітних ризиків. Це й відображається на вартісних характеристиках конкуренції у сегменті, який розглядається (рис. 1). Як відомо, загальний підхід представлено у роботі [6]. На ринку морської торгівлі необхідно враховувати особливості формування та прояви п'яти конку- рентних сил позиціонування флоту та портів 3 виокремленням характеру прояву різних видів загроз.

Під час вибору стратегії розвитку будь-якої підсистеми морської транспортної індустрії та постановки поточного завдання розвитку необхідно розрізняти особливості формування внутрішнього середовища $\mathrm{i}$ характер прояву зовнішніх факторів усталеності позиціонування. Принциповим стає необхідність врахування складності прояву фактору часу.

Основний матеріал дослідження. Під час оцінки стану сегменту або маршруту операторської діяльності слід враховувати мінливість прояву всіх можливих ризиків та загроз для стабільності позиціонування. Важливо оцінити підприємницькі переваги відносно зовнішніх негативних екстерналій.

Потенційні учасники морських транспортних технологій, формуючи реальні переваги позиціонування на ринку морської торгівлі, повинні сприймати допустимі ризики змінення характеру збалансованості попиту та пропозиції.

Принциповим лишається характер усталеності обраного для операторської діяльності сегменту ринку морської торгівлі. Особливо це стосується судновласницьких компаній 3 недостатньою концентрацією провізної здатності флоту, котрі не володіють перевагами економіки масштабу. У системі сталого позиціонування судноплавних компаній необхідно враховувати не тільки положення основних учасників ринку морської торгівлі (рис. 1), а й характер очікуваного прояву системних ризиків та загроз. 


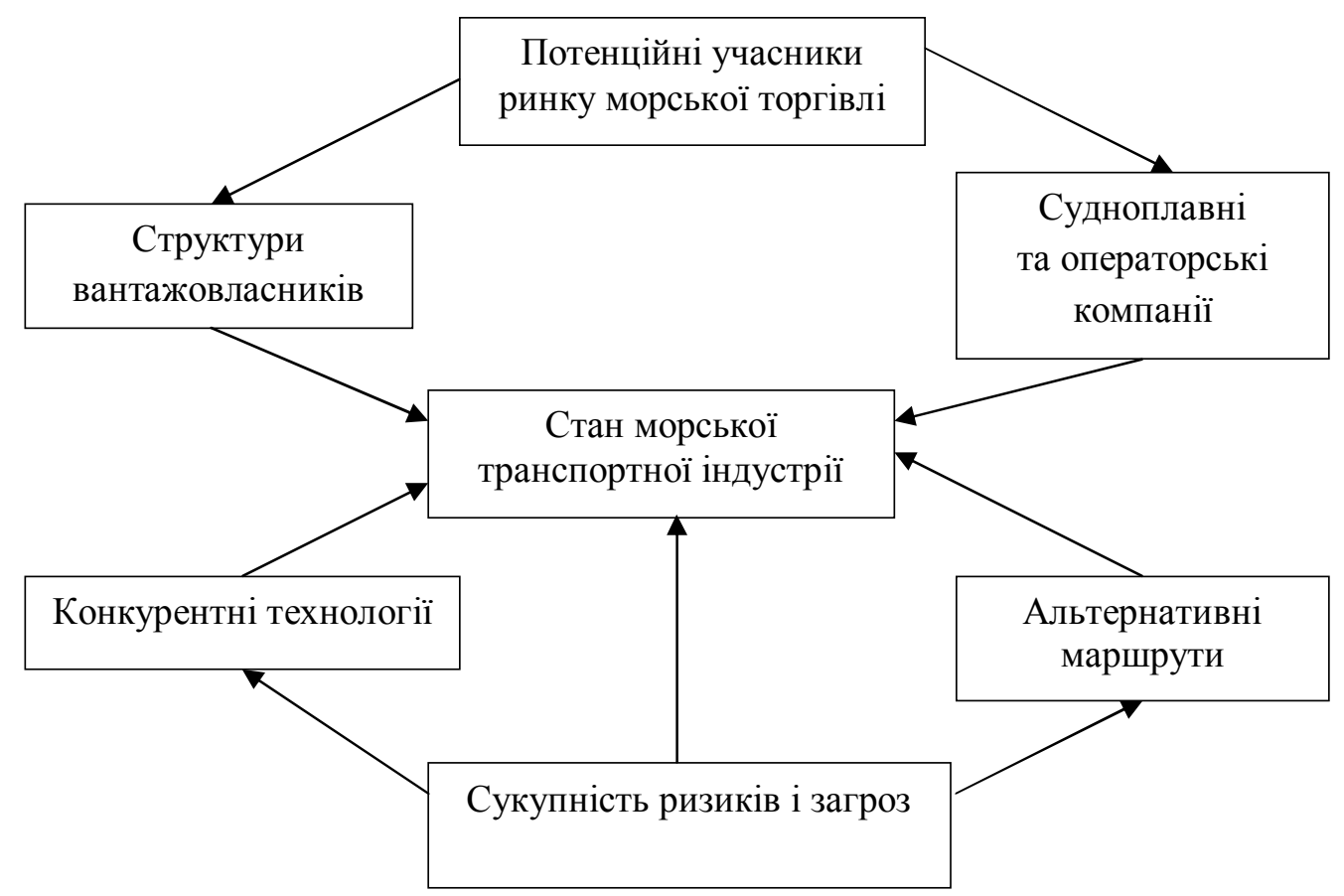

Рис. 1. Особливості формування конкурентного середовища у системі ринку морської торгівлі

Джерело: розроблено авторами

Поміж них варто відзначити відсутність або обмеженість потужностей прийому та очищення відходів 3 транспортних суден у національних портах, особливо річкових. Тому виникає проблема для повномасштабного судноплавства, перш за все Дніпром. Як зазначається у публікації [7], ризики за категорією безпеки судноплавства пов'язані й з великою кількістю створених експедиторських, стивідорних та агентських фірм, що забезпечують обробку для морської доставки небезпечних вантажів. Їхні спеціалісти найчастіше не володіють відповідною компетенцією для безпечної організації процесу перевезення.
Підвищення ролі інноваційних напрямків розвитку морських транспортних підприємств 3 одночасним обмеженням доступу до інвестиційних ресурсів ряду структур зумовлює зростання концентрації виробничого потенціалу. Фактично, глобалізація визначає пріоритет монополізації окремих підсистем морської транспортної індустрії як фактору конкурентоспроможності.

Слід звернути увагу на той факт, що інноваційний розвиток підсистем морської транспортної індустрії значною мірою зумовлюється вимогами 3 боку Міжнародної морської організації щодо забезпечення системної безпеки. Тому, в цілому, всі вдосконалення техніко-економіч- 
DEVELOPMENT OF MANAGEMENT

AND ENTREPRENEURSHIP METHODS ON TRANSPORT, № 3 (72), 2020
РОЗВИТОК МЕТОДІВ

УПРАВЛІННЯ ТА ГОСПОДАРЮВАННЯ

НА ТРАНСПОРТІ, № 3 (72), 2020 них характеристик флоту не призводять до помітного підвищення ефективності підприємницької діяльності.

Внутрішнє середовище відображає характер формування власності та ефективність реалізації іiі економічного потенціалу. Цей процес достатньо описаний методами, показниками i критеріями. Головною стає чіткість відображення характеру впливу зовнішнього середовища.

Саме тут панує ймовірність прояву і сприйняття реальної ситуації у глобальному транспортному судноплавстві. Для характеристики розвитку інноваційних параметрів підсистем морської транспортної індустрії достатньо чітко враховувати сукупність зовнішніх загроз. Поміж них слід розрізняти змінення:

- умов використання транзитного простору;

- ставок різних зборів та оподаткування;

- законів і норм операторської діяльності та використання економічних ресурсів на рівні ММО;

- конкурентного середовища на підставі монополізації або інноваційних технологій.

Тому найважливішою стає оцінка особливостей реакції окремих підсистем морської транспортної індустрії на ці зміни (рис. 1). Головним стає обрання бізнес-позиції за номінальними пріоритетами відносно різкого посилення вимог провідних операторів ринку морської торгівлі. При цьому використовується принцип симетрії стійкого розвитку окремих підсистем глобальної економіки, заснованої на досягненні підприємницьких інтересів в умовах чіткого прояву абсолютних та порівняльних переваг.
Серед ризиків збереження сталого позиціонування вирізняється поява нових економічних союзів, які змінюють маршрутизацію перевезення вантажів. Це зумовлює змінення параметрів використання флоту окремих прапорів. Водночас помітно змінюється завантаження базових портів, що використовують стандартні технології. Це - одна 3 причин активізації Китаю і «DP World» у стратегії концесійного управління іноземними портами у всьому просторі глобального ринку морської торгівлі.

Саме орієнтація порту Констанца на стратегію інтеграції й впливає на мінімізацію завантаження порту Чорноморськ у структурі фідерних технологій. При цьому український порт знаходиться у зоні більш високого конкурентного транзитного простору.

У будь-яких стратегіях формування конкурентної позиції важливим $\epsilon$ прийняття симетричних економічних рішень (рис. 2).

В Україні фактична монопольна структура - Адміністрація морських портів України - не вписується ні у Стратегію-30, ні в рамкові принципи доступу до ринку портових послуг. У світовій практиці саме адміністрації окремих портів на основі своєї діяльності формують оптимальність співвідношення доходів та витрат, що дозволяє оптимізувати розвиток за критеріями ефективності.

Слід враховувати, що ринкові принципи економічних відносин на будь-якому рівні визначають пріоритет підприємницьких стратегій, а не адміністративних технологій управління. 
Як видно 3 рис. 2, трансформаційні процеси як реакція на наявність ризиків передбачають необхідність урахування реальної ситуації на ринку морської торгівлі. Реакція сприйняття й формує обмеженість підходів у системі менеджменту реалізації програми сталого позиціонування на глобальному ринку морської торгівлі.

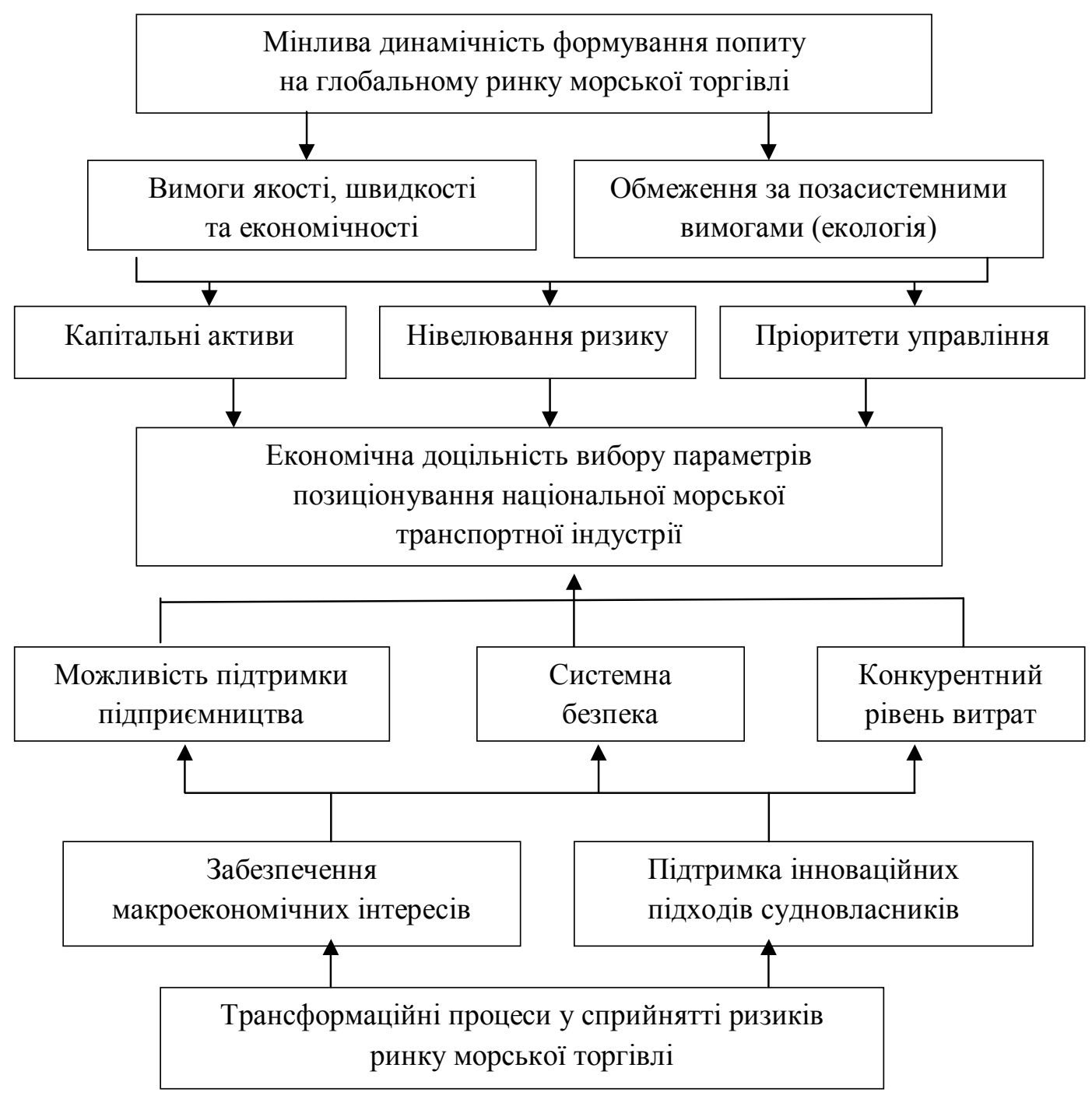

Рис. 2. Принциип симетрії прийняття економічних рімень у сукупності ризиків торгового судноплавства

Джерело: розроблено авторами 
DEVELOPMENT OF MANAGEMENT

AND ENTREPRENEURSHIP METHODS ON TRANSPORT, № 3 (72), 2020
РОЗВИТОК МЕТОДІВ

УПРАВЛІННЯ ТА ГОСПОДАРЮВАННЯ

НА ТРАНСПОРТІ, № 3 (72), 2020
Вочевидь, економічна доцільність вибору параметрів позиціонування національної морської транспортної індустрії має двосторонню обумовленість. 3 одного боку, принципове значення має характер динамічності параметрів попиту на ринку морської торгівлі. 3 іншого боку, під впливом низки зовнішніх і внутрішніх факторів необхідно враховувати трансформацію реакції та нейтралізації сукупності ризиків сталого позиціонування у системі товарообмінних операцій.

Всі види ризиків повинні розглядатись як природна складова результативності формування та відповідного використання економічного потенціалу судноплавного підприємства. В принципі, необхідно враховувати, що діяльність підсистеми, яка забезпечує безпеку судноплавства, не націлена на формування доходів. Ця діяльність характеризується витратами. При цьому вони не залежать від економіки масштабу. Кожен об'єкт, який формує умови судноплавства, незалежно від кількості суден, які проходять, має мінімізувати ризики. Тобто величина витрат, керуючих безпекою підсистем за критеріями мінімуму ризику, характеризується нормалізованим рівнем витрат. Тому важливо мати чіткі джерела їхнього фінансування.

Якщо розглядати спрямованість ініціативи «Один пояс - один шлях» на інноваційне обслуговування вантажопотоків, тоді варто орієнтуватись на вимоги відповідних маршрутів до технологій, які забезпечують точність часу доставки вантажів. Стійкість зростання одиничної капіталомісткості транспортного флоту обумовлює вимоги до менеджменту його діяльністю на основі моделі САРМ (Capital asset pricing model). Слід враховувати, що залучення різних інвестиційних джерел для формування капітальних активів судновласника знижує прояв окремих ризиків. У цьому аспекті особливе місце займають концесійні стратегії, особливо 3 урахуванням диференціації маршрутів, зумовленої ініціативою реалізації «Нового шовкового шляху».

Сучасні інноваційні підходи до забезпечення стійкості судноплавних компаній у системі ринку морської торгівлі, незважаючи на додаткові витрати, забезпечують ефективність на підставі управління адекватністю до змін [8]. Тому і інформаційні проекти, і екологічні обмеження формують параметри конкурентних позицій за зовнішніми вимогами та обмеженнями. Вони дозволяють розвиватись за стандартами різних екстерналій. Тому певною мірою змінюється норма підприємницької ефективності. Переваги зсуваються на позицію економіки системи, а не разової ефективності.

У цьому відношенні активізація позиції щодо розвитку «Нового шовкового шляху» маршрутами Туреччини, Румунії та Болгарії обумовлює появу ризику для українського позиціонування. Він зумовлений пасивністю підходу інституціональних структур країни і обмеженістю ресурсів у підприємницьких підсистем. Конкуренти формують показники надійності та економічності доставки вантажів у коридорі Схід-Захід. Для входження до сегменту нових операторів необхідна наявність високопродуктивних та економічних суден. Цим 
DEVELOPMENT OF MANAGEMENT

AND ENTREPRENEURSHIP METHODS ON TRANSPORT, № 3 (72), 2020
РОЗВИТОК МЕТОДІВ

УПРАВЛІННЯ ТА ГОСПОДАРЮВАННЯ

НА ТРАНСПОРТІ, № 3 (72), 2020 вимогам відповідають пороми «RoРах», проект яких розроблений Одеським інженерним бюро.

Нажаль, в Україні, на відміну від Азербайджану, не використовується стандартна стратегія підтримання окремих складових морської транспортної індустрії. Необхідний спеціальний економічний механізм, який розкриває принципи та напрями подолання інвестиційного бар'єру для входження до структури «Нового шовкового шляху». Цей проект варто розглядати як інтеграційне співробітництво окремих держав 3 одночасним формуванням пріоритетів 3 боку конкретного учасника. Саме за умови слабкості ініціативи Україна й втрачає природні переваги транзитного потенціалу.

Тобто до системи ризиків, що може бути обумовлена появою нових маршрутів або інноваційних рішень конкурентів, слід віднести можливе скорочення використання виробничого потенціалу, пов'язаного із зниженням прибутковості.

При цьому постійне ускладнення умов розвитку і функціональної діяльності судноплавних компаній визначає реальність фінансових ризиків: падіння норми прибутку, обмеження зростання операційного прибутку та утримання ефективності використання капітальних активів.

Морське середовище за гідрометеорологічними характеристиками поряд з глобальними кризами формує структуру некерованих ризиків для судновласницьких структур. У якості реакції на перші умови підвищується роль інноваційних технологій, котрі знижують негативні наслідки за рахунок більш високої капіталоміст- кості. Друга складова ризиків формує системні втрати. Наприклад, внаслідок кризи 2009 року обсяг замовлень на суднобудування знизився у два рази, що й зумовило банкрутство половини верфей світу. Одночасно пішла з ринку морської торгівлі низка судноплавних компаній, поміж яких були ті, які раніше вирізнялись помітною концентрацією провізної здатності флоту. Останнє й вимагає виділення факторів впливу системи управління на зниження імовірності прояву окремих видів ризиків. Саме досягнення відповідності національної морської транспортної індустрії провідним ланкам розвитку знижує ризик стану неадекватності інтермодальним технологіям.

Український транзитний потенціал з урахуванням активізації морської державної політики може підвищити свою віддачу на основі концентрації уваги на обліку частоти i партіонності відповідних залізничних маршрутів та конкурентних залізничних поромів.

Висновки. Для досягнення усталеності позиціонування у локальних сегментах ринку морської торгівлі виділяється стратегія реакції на прояв групи операційних ризиків. Серед яких виділяються: можлива неплатоспроможність фрахтувальника, форс-мажорні умови у зоні операторської діяльності та різні несистемні ризики, у структурі останніх періодично проявляється й сучасне піратство, що використовує високоякісні інформаційні технології. Тому використовується інструментарій страхування від можливих втрат.

Україна, незважаючи на істотне падіння валютного курсу національ- 
ної грошової одиниці 3 моменту іiі створення і відповідного здешевлення експорту, не змогла домогтися розширення позиції на глобальному ринку торгівлі через відсутність продукції з високою доданою вартістю. Це обмежує вантажопотік, і 90 відсотків флоту зареєстровано у реєстрах зручного прапора. I отже, ця позиція не забезпечує позитивного сальдо рахунку поточних платежів.

Наскільки б дивним це не видавалось, але технологія обробки зерновозів на рейді без заходу до гирлових портів з обмеженою глибиною підхідного каналу стає ризиком конкурентоспроможності ряду портів, особливо 3 огляду на величини ставок портових зборів. Наприклад, можливості «НІБУЛОН» дозволяють вироб- ляти рейдове навантаження 3 нормою 40 тисяч тон на добу. Це вписується у відповідний типорозмір-ний ряд зерновозів.

Принциповим для відповідних судновласницьких структур та морських портів стає концентрація часу i капітальних активів на реалізації відповідних інноваційних проектів розвитку. Ефективність цього процесу може характеризуватись моментом досягнення розриву поточних витрат $\mathrm{i}$ величини тарифних ставок рівноваги у сегменті фрахтового ринку, котрий забезпечує необхідну норму прибутку. Саме відсутність ситуації ціни рівноваги на глобальному ринку морської торгівлі й обмежує використання флоту таких морських держав як Україна.

\section{СПИСОК ЛІТЕРАТУРИ}

1. Primachev, N., Fracinuk, T. Ukraine an Example of Limits of Balance and Asymmetric Reaction in the Maritime Trade Market. Electronic Scientific Journal PREGLAD WSCHODIOEUROPEISKI. 2019. X/1, 2019, p. 153-161. DOI: $10.31648 / p w .4511$.

2. Шевченко M. Maersk: логістичне рімення «nід ключ» // Порти Украӥни. № 6, 2019. C. 36-37.

3. Адізес І.К. Управління життєвим цииклом корпорацій; пер. з англ. СПб.: Пimep, 2007. $384 \mathrm{c}$.

4. Molnare, Eva. Trends in Transport Investment Funding: Past, Present and Future // Fifty Years of Transport Policy Successes, Failures and New Challenges: Transport OECD, 2003. P. 70-78.

5. Транспортна стратегія Украӥни на період до 2020 року. Київ: Мінінфраструктури, 2011. 63 с.

6. Портер М. Конкуренція. Пер. з англ. М.: Видавничий дім «Вільямс». 2005. $602 \mathrm{c}$.

7. Чистяков В. Проблеми вантажної безпеки судноплавства // Sea Review, 3(71). The International Maritime Journal , p. 7-9

8. Крістенсен К. Що далі? Теорія інновацій як інструмент передбачення галузевих змін / С. Ентоні, Е. Рот; Пер з англ. М.: Альпіна Паблішер, 2015. $400 \mathrm{c}$. 
9. Примачев Н.Т., Примачева Н.Н., Пархоменко И.Н. Управление экономической деятельностью судоходных компаний. Одесса: НУ «ОМА», 2016. $346 c$.

10. Котлубай О.М. Економічні механізми розвитку торговельного мореплавання в Україні. Одеса: ІПРта ЕЕД, 2004. 454 с.

11. Кібік O.M., д.е.н., проф., ORCID 0000-0001-9587-578X, https:// orcid. org/ 0000-0001-9587-578X Svitlana Filyppova, Valery Okulich-Kazarin, Olha Kibik, Grygoriy Shamborovskyi, Svitlana Cherkasova. Influence of the market of business intellectual services on the innovation safety of eu countries. JOURNAL OF SECURITY AND SUSTAINABILITY ISSUES / 2019 September Volume 9 Number 1. http://doi.org/10.9770/jssi.2019.9.1(26)

12. Kurudzhi, Yu., Moskvichenko, I., Postan, M. Method of finding equilibrium solutions for duopoly of supply chains taking into account the innovative activity of enterprises/ Yu. Kurudzhi, // Eastern-European Journal of Enterprise Technologies. 2017.\#3/4 (87). P. 25-30. DOI:10.15587/17294061.2017.103989

13. Kosharskaya, L., Makhurenko, G., Postan, M. Application of the system approach to the development of the project of a safety management system for navigation in Ukraine // Eastern-European Journal of Enterprise $\begin{array}{llllll}\text { technologies. } & 2017 . & \# 4 / 2 & \text { (36). } & P . & 29-36 .\end{array}$ DOI: $10.15587 / 2312-8372.2017 .109094$

14. Котлубай О.М., Познанська I.В., Липинська О.А. та інші. Розвиток економічних взаємовідносин в світовому транспортному комплексі: монографія. Одеса, 2013. 206 с

15. Commentary of market. URL: https://www.sea-intelligence.com.

\section{REFERENCES}

1. Primachev, N., Fracinuk, T. (2019), Ukraine an Example of Limits of Balance and Asymmetric Reaction in the Maritime Trade Market. Electronic Scientific Journal PREGLAD WSCHODIOEUROPEISKI. X/1, p. 153-161. DOI: 10. $31648 / p w .4511$

2. Shevchenko, M. (2019). Maersk: logistichnerishenny «pidkluch». [Maersk: turnkey logistics solution]. Portu Ukrain - Ports of Ukraine. 6, 36-37 [in Ukraine]

3. Adizes, I. (2007) Upravliny gitevum ciklom korporaciy [Corporate life cycle management]. SPb., Piter, 384 [in Russian].

4. Molnare, Eva, (2003). Trends in Transport Investment Funding: Past, Present and Future // Fifty Years of Transport Policy Successes, Failures and New Challenges: Transport OECD, 70-78.

5. Transportnay strategiy Ukraine na period do 2020. Kiev (2011). Mininfrastrukturu. 63 [in Ukkraine].

6. Porter, M. (2005). Konkurenciy. M .: Williams Publishing House. 602 [in Russian]. 
7. Chistyakov, V. Problemu vantagnoy bezpeku sudnoplavstva [Problems of cargo safety of navigation]. The International Maritime Journal, Sea Review p. 7-9 [in Ukrainian]

8. Kristencen, K. (2015) Sho dali? Teoriy innovaciy yk instrument peredbachenny galuzevuh zmin [What's next? Theory of innovation as a tool for predicting sectoral changes]. Alpina Pabliser 400.

9. Prymachev, N.T., Prymacheva, N.N. \& Parkhomenko, Y.N. (2016). Upravlenye ékonomycheskoy deyatelnost' Yu sudokhodnykh kompanyy [Management of Shipping Companies Economic]. Odessa NU «OMA», 346 [in Russian].

10. Kotlubay, O.M. (2004). Ekonomichni mekhanizmy rozvytku torhivelnoho moreplavannya $v$ Ukrayini [Economic mechanisms for the development of commercial navigation in Ukraine. Odesa: IPRtaEED , 454 [in Ukrainian].

11. Olha, Kibik, Svitlana, Filyppova, Valery, Okulich-Kazarin, Grygoriy, Shamborovskyi \& Svitlana Cherkasova (2019). Influence of the market of business intellectual services on the innovation safety of eu countries. Journal of security and sustainability issues/September Volume 9 Number 1. http://doi. org/ 10.9770/jssi. 2019.9.1(26).

12. Postan M. Kurudzhi Yu. \& Moskvichenko I. (2017). Method of finding equilibrium solutions for duopoly of supply chains taking into account the innovative activity of enterprises. Eastern-European Journal of Enterprise Technologies. \#3/4 (87). P. 25-30. DOI:10.15587/1729-4061.2017.103989.

13. Kosharskaya, L., Makhurenko, G. \& Postan, M. (2017). Application of the system approach to the development of the project of a safety management system for navigation in Ukraine // Eastern-European Journal of Enterprise technologies. \#4/2 (36). P. 29-36. DOI:10.15587/2312-8372.2017.109094.

14. Kotlubay, O. (2013) Poznanska I., Lipinska A. ta inshi Rozvutok ekonomichnuh vzaemovidnosen $v$ svitovomu transportnomu kompleksi: monografiy [Development of economic relations in the world transport complex. Odessa, 206 [in Ukraine].

15. Commentary of market. Retrieved from: https://www.sea-intelligence.com

Стаття надійшла до редакиії 18.09.2020

Посилання на статтю: Сєнько О.В., Стахов А.Ю. Управління ефективністю торгового судноплавства $\mathrm{p}$ урахуванням системи ризиків // Розвиток методів управління та господарювання на транспорті: Зб. наук. праць, 2020. № 3 (72). С. 109-120. DOI 10.31375/2226-1915-2020-3-109-120.

Article received 18.09.2020

Reference a JournalArtic: Sienko, Olena \& Stakhov, Arsenii (2020). Merchant shipping efficiency management with allowance for the system of risks. Development of management and entrepreneurship methods on transport, 3 (72), 109-120. DOI 10.31375/2226-1915-2020-3-109-120. 